\title{
Caddo Ceramic Vessels from the A. C. Gibson Site (41WD1) in the Sabine River Valley, Wood County, Texas
}

Timothy K. Perttula

Heritage Research Center, Stephen F. Austin State University

Bob D. Skiles

Follow this and additional works at: https://scholarworks.sfasu.edu/ita

Part of the American Material Culture Commons, Archaeological Anthropology Commons, Environmental Studies Commons, Other American Studies Commons, Other Arts and Humanities Commons, Other History of Art, Architecture, and Archaeology Commons, and the United States History Commons

Tell us how this article helped you.

This Article is brought to you for free and open access by the Center for Regional Heritage Research at SFA ScholarWorks. It has been accepted for inclusion in Index of Texas Archaeology: Open Access Gray Literature from the Lone Star State by an authorized editor of SFA ScholarWorks. For more information, please contact cdsscholarworks@sfasu.edu. 


\section{Caddo Ceramic Vessels from the A. C. Gibson Site (41WD1) in the Sabine River Valley, Wood County, Texas}

\section{Creative Commons License}

\section{(c) (1) (8)}

This work is licensed under a Creative Commons Attribution-NonCommercial 4.0 International License 


\title{
The Harold Nix Site in Morris County, Texas: A Late Titus Phase Cemetery on Boggy Creek in the Big Cypress Creek Basin
}

\author{
Timothy K. Perttula
}

\section{Introduction}

The Harold Nix site is an ancestral Caddo cemetery excavated in 1995 and 1996 by Ralph Nicholas and colleagues on land owned by Harold Nix on a sandy landform along a small tributary to Boggy Creek, itself a southward-flowing tributary to Big Cypress Creek, in Morris County, Texas (Figure 1). The site was discovered during backhoe work on the property in July 1975, and Mr. Nix asked Nicholas to excavate the cemetery. The exact location of the site is not known and a state trinomial has not been assigned the site at this time. Nicholas' notes on the excavations and collections were turned over to Robert L. Turner, Jr., and he then turned those notes over to the Texas Archeological Research Laboratory at The University of Texas at Austin in August 1998, along with his notes and comments. These notes are employed herein to discuss the character of the ancestral Caddo cemetery, which apparently dates sometime between ca. A.D. 1550-1680 during the late Titus phase, and the associated funerary offerings in the 20 burial features.

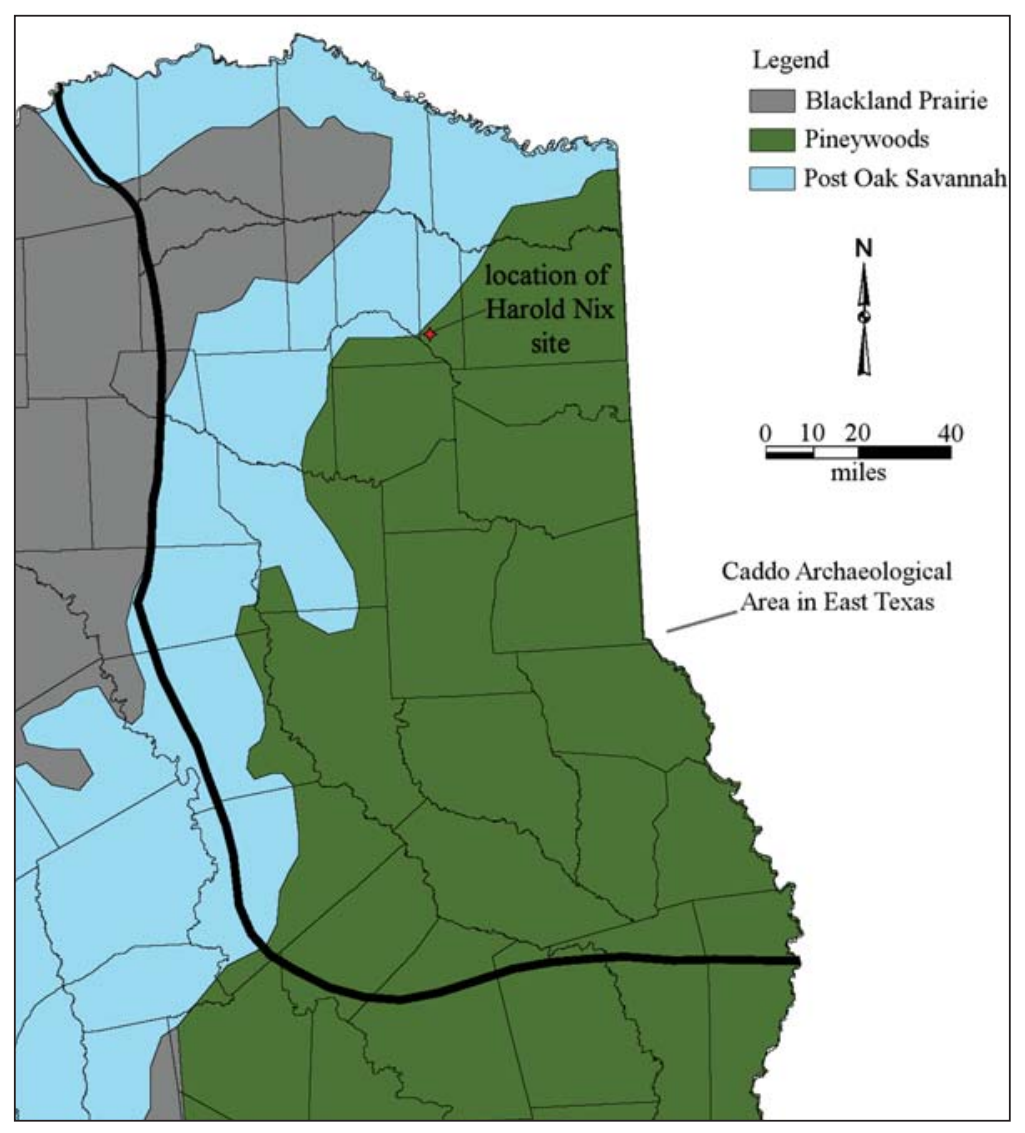

Figure 1. General location of the Harold Nix site in East Texas. 


\section{The Cemetery}

The late Titus phase cemetery at the Harold Nix had 20 individual burial features arranged in apparent northeast-southwest rows (Figure 2). The size of the cemetery suggests it is a family cemetery that was used by nearby communities of Caddo peoples (see Perttula 2012:395). The burial pits extended to ca. $90-110 \mathrm{~cm}$ bs in depth, and several extended below the current water table. All of the burials had funerary offerings, particularly ceramic vessels (Table 1).

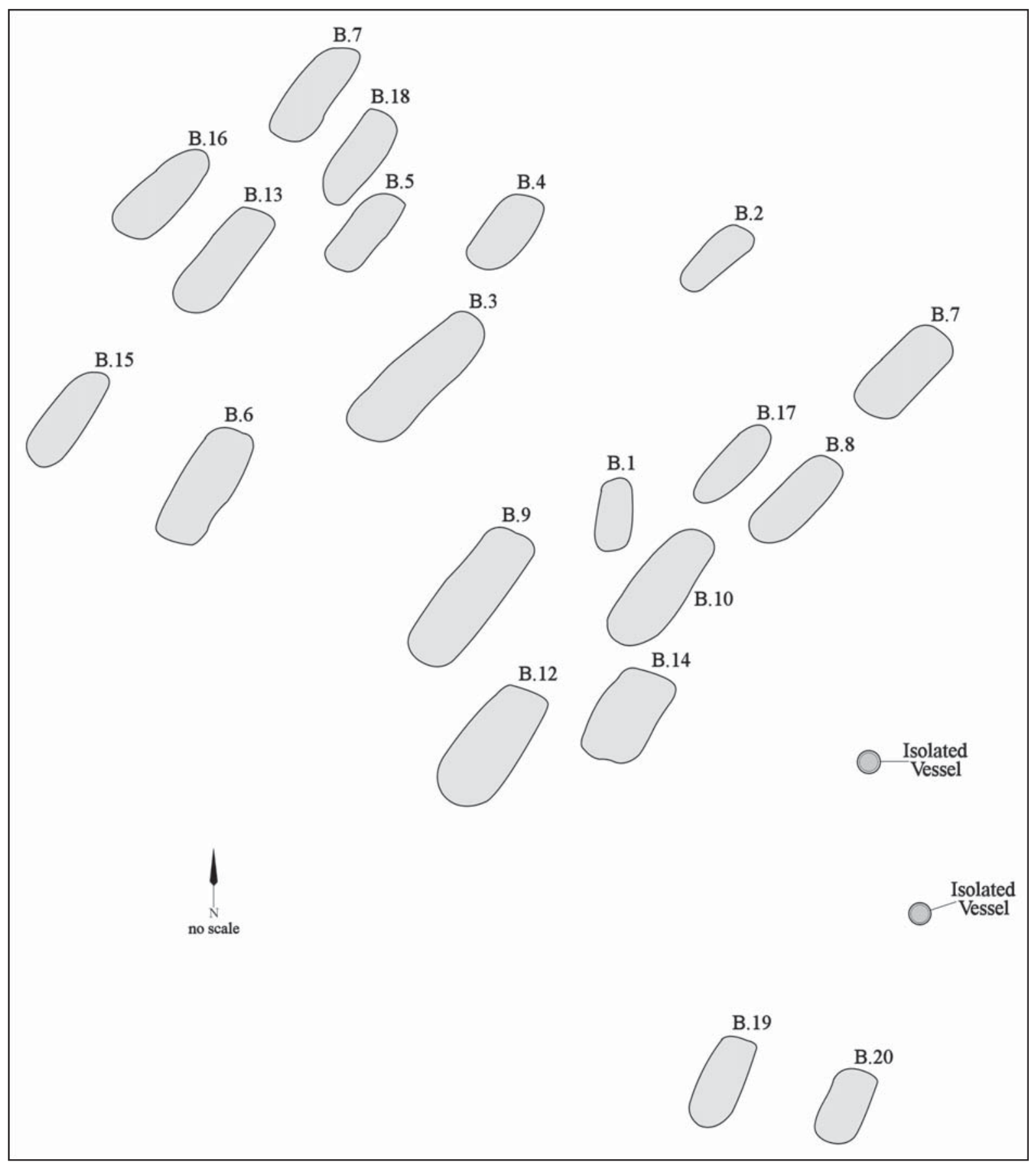

Figure 2. Plan of the cemetery at the Harold Nix site. 
Table 1. Funerary offerings in individual burials at the Harold Nix site.

\begin{tabular}{|c|c|c|c|c|c|c|}
\hline Burial No. & Vessels & Pipe & Ear Spool & Talco Points & Celt & $\mathrm{N}$ \\
\hline 1 & 4 & 1 & 1 & 1 & - & 7 \\
\hline 2 & 4 & - & - & - & - & 4 \\
\hline 3 & 7 & - & - & - & 1 & 8 \\
\hline 4 & 4 & - & - & - & - & 4 \\
\hline 5 & 5 & - & - & - & - & 5 \\
\hline 6 & 6 & - & - & - & - & 6 \\
\hline 7 & 4 & - & - & - & - & 4 \\
\hline 8 & 13 & - & - & - & - & 13 \\
\hline 9 & 7 & - & - & - & - & 7 \\
\hline 10 & 5 & - & - & 3 & - & 8 \\
\hline 11 & 6 & - & - & - & - & 6 \\
\hline 12 & 5 & - & - & - & 1 & 6 \\
\hline 13 & 8 & - & - & 22 & - & 30 \\
\hline 14 & 3 & - & - & - & - & 3 \\
\hline 15 & 3 & - & - & - & - & 3 \\
\hline 16 & 2 & - & - & - & - & 2 \\
\hline 17 & 7 & - & - & - & - & 7 \\
\hline 18 & 6 & - & - & - & - & 6 \\
\hline 19 & 11 & - & - & - & - & 11 \\
\hline 20 & 8 & - & - & - & - & 8 \\
\hline Totals & 118 & 1 & 1 & 26 & 2 & 148 \\
\hline
\end{tabular}

The mean number of funerary offerings per burial is 7.4, with a range of 2-30 offerings (see Table 1). The frequency of funerary offerings in the burials at the Harold Nix site is among the lowest of any documented Titus phase cemetery (Perttula 2012:Table 13-4).

Ceramic vessels comprise about 80 percent of the funerary offerings, with a mean of 5.9 vessels per burial (with a range of 2-13 vessels) at the Harold Nix site; two other vessels were recovered east of Burial 14 that were not in obvious burial pits (see Figure 2), but likely mark unrecognized burials, perhaps those of children. Other funerary offerings include a ceramic pipe and ear spool from Burial 1, 26 Talco arrow points from three burial features (a mean of 1.3 points per burial), and two ground stone celts from two other burial features (see Table 1).

\section{Funerary Offerings}

\section{Ceramic Vessels}

The notes and compilations by Ralph Nicholas indicated that 118 ceramic vessels were funerary offerings in the 20 burials, and two other isolated vessels (from unrecognized burials?) were also recovered in the work. Although the total number of ceramic vessels from the Harold Nix site is known, it is not possible to identify every vessel from each burial feature by either a defined type or a vessel form, because in several instances, Nicholas' compilation simply lists the number of vessels from a burial, and nothing more. Relying on Nicholas' compilation of the ceramic vessels from the burial features, plus his drawings of rim motifs, permits the identification of 10 different defined ceramic types from 16 burials in the cemetery and the two isolated vessels from unidentified burials (Table 2).

Table 2. Identified ceramic vessel types in burials at the Harold Nix site. 


\begin{tabular}{|c|c|c|c|c|c|c|c|c|c|c|}
\hline Burial No. & $\mathrm{HL}$ & LR & RI & $\mathrm{CS}$ & BA & MY & TA & SI & NB & TE \\
\hline 1 & $\mathrm{x}$ & & & & & & & & & \\
\hline 2 & & $\mathrm{x}$ & $\mathrm{x}$ & & & & $\mathrm{x}$ & & & \\
\hline 5 & & & & & & & & $\mathrm{x}[\mathrm{BE}]$ & & \\
\hline 6 & & & & & & & & $\mathrm{x}$ & & \\
\hline 7 & & & $\mathrm{x}$ & $\mathrm{x}$ & & & & & & \\
\hline 8 & $\mathrm{x}$ & $\mathrm{x}$ & $\mathrm{x}$ & & $\mathrm{x}$ & $\mathrm{x}$ & & $\mathrm{x}$ & & $\mathrm{x}$ \\
\hline 10 & & & $\mathrm{x}$ & & & & $\mathrm{x}$ & & & \\
\hline 11 & $\mathrm{x}$ & & $\mathrm{x}$ & & $\mathrm{x}$ & & & $\mathrm{x}$ & & \\
\hline 12 & & & $\mathrm{x}$ & & $\mathrm{x}$ & & & & & \\
\hline 13 & & & $\mathrm{x}$ & & $\mathrm{x}$ & & & & & \\
\hline 14 & & $\mathrm{x}$ & $\mathrm{x}$ & & & & & & & \\
\hline 15 & & & $\mathrm{x}$ & & & & & & $\mathrm{x}$ & \\
\hline 16 & & $\mathrm{x}$ & $\mathrm{x}$ & & & & & & & \\
\hline 17 & & & $\mathrm{x}$ & & & & & & & \\
\hline 18 & $\mathrm{x}$ & $\mathrm{x}$ & $\mathrm{x}$ & & & & & & & \\
\hline 19 & & & $\mathrm{x}$ & & & $\mathrm{x}$ & & & & \\
\hline 20 & & & $\mathrm{x}$ & & & & & & & \\
\hline UID & & & $\mathrm{x}$ & & & & & & & \\
\hline
\end{tabular}

$\mathrm{x}=$ present

HL=Harleton Appliqued; LR=LaRue Neck Banded; RI=Ripley Engraved; CS=Cass Appliqued; BA=Bailey Engraved; MY=Maydelle Incised; TA=Taylor Engraved; SI=Simms Engraved; BE=Bowie Engraved; NB=Nash Neck Banded; TE=Turner Engraved

Ripley Engraved vessels occurred in 14 of the 17 burials listed in Table 2 ( 82 percent), and it is by far the most common fine ware vessel offering at the Harold Nix cemetery. Bailey Engraved bottles are in four burial features (24 percent), three burial features have Simms Engraved vessels (18 percent), and there were two burial features (11.8 percent) that had Taylor Engraved vessels (see Table 2). One burial had a Turner Engraved compound bowl (6 percent), and another burial had a shell-tempered Bowie Engraved vessel (6 percent). Among the utility wares, the most common vessel offerings were La Rue Neck Banded jars in five burial features (29 percent) and Harleton Appliqued jars in four burial features (24 percent). Two burial features (11.8 percent) had Maydelle Incised jars, and two different burial features had either a Cass Appliqued or a Nash Neck Banded jar (see Table 2); the Nash Neck Banded jar, likely shell-tempered, was a vessel obtained from a McCurtain phase Red River Caddo group.

As best as can be determined from the notes, 65 vessels can be linked with a defined type; the others are a mixture of Bailey Engraved, Wilder Engraved, and Ripley Engraved bottles $(n=11)$ that are not identified by type or burial feature, miscellaneous utility wares, and pigment bowls $(n=2)$ from Burials 17 and 19. More than 66 percent of these vessels are Ripley Engraved bowls $(n=2)$, carinated bowls $(n=35)$, and compound bowls $(n=4)$. Other fine wares in the sample of 65 vessels include Bailey Engraved $(n=4$, 6.2 percent), Taylor Engraved ( $n=2,3.1$ percent), Simms Engraved $(n=2,3.1$ percent), Bowie Engraved $(\mathrm{n}=1,1.5$ percent), and Turner Engraved ( $\mathrm{n}=1,1.5$ percent). Among the utility wares are La Rue Neck Banded ( $n=5,7.7$ percent), Harleton Appliqued ( $n=4,6.2$ percent), Maydelle Incised ( $n=2,3.1$ percent), Cass Appliqued ( $\mathrm{n}=1,1.5$ percent), and Nash Neck Banded $(\mathrm{n}=1)$.

Photographs in the file of vessels from non-attributed burial features at the Harold Nix site also show a spool-necked engraved bottle with a hooked arm element and large triangular-shaped areas filled with excised punctations, as well as four Wilder Engraved, var. unspecified bottles. There is also a large Ripley Engraved olla with a central circle and cross motif (cf. Suhm and Jelks 1962:Plate 65k).

Nicholas made rim motif drawings for the engraved fine ware vessels $(n=49)$ in Burials 2-10, and 
these are employed to identify specific fine ware types as well as a number of varieties of Ripley Engraved (Figure 3) in the vessel assemblage. The most common variety of Ripley Engraved in the Harold Nix burial features (Burials 2-10) is var. McKinney (Figure 4u-v); this variety accounts for 45 percent of the fine wares in these burials. Another 22.5 percent are vessels of a newly defined Ripley Engraved variety: var. Nix (Figure 5a-k). This distinctive variety is related to var. McKinney because of the upper and lower excised pendant triangle elements on the rim panel, but differs from var. McKinney because it lacks the central circle or diamond elements. This variety may also be related to Ripley Engraved, var. McKinney-Enis Smith defined by Fields et al. (2014:Table 8.6), but none of the var. Nix vessels from the Harold Nix site have "rounded abutting scroll ends" (Fields et al. 2014:Table 8.6). Instead, var. Nix pendant triangles have a simple horizontal and vertical scroll and vertical dividers of several kinds. Other than the Harold Nix site, the only other known example of Ripley Engraved, var. Nix in the East Texas vessel database of more than 8000 vessels is one carinated bowl from the ca. A.D. 1550-1680 McKinney site (41MR12), downstream from the Harold Nix site on Big Cypress Creek.

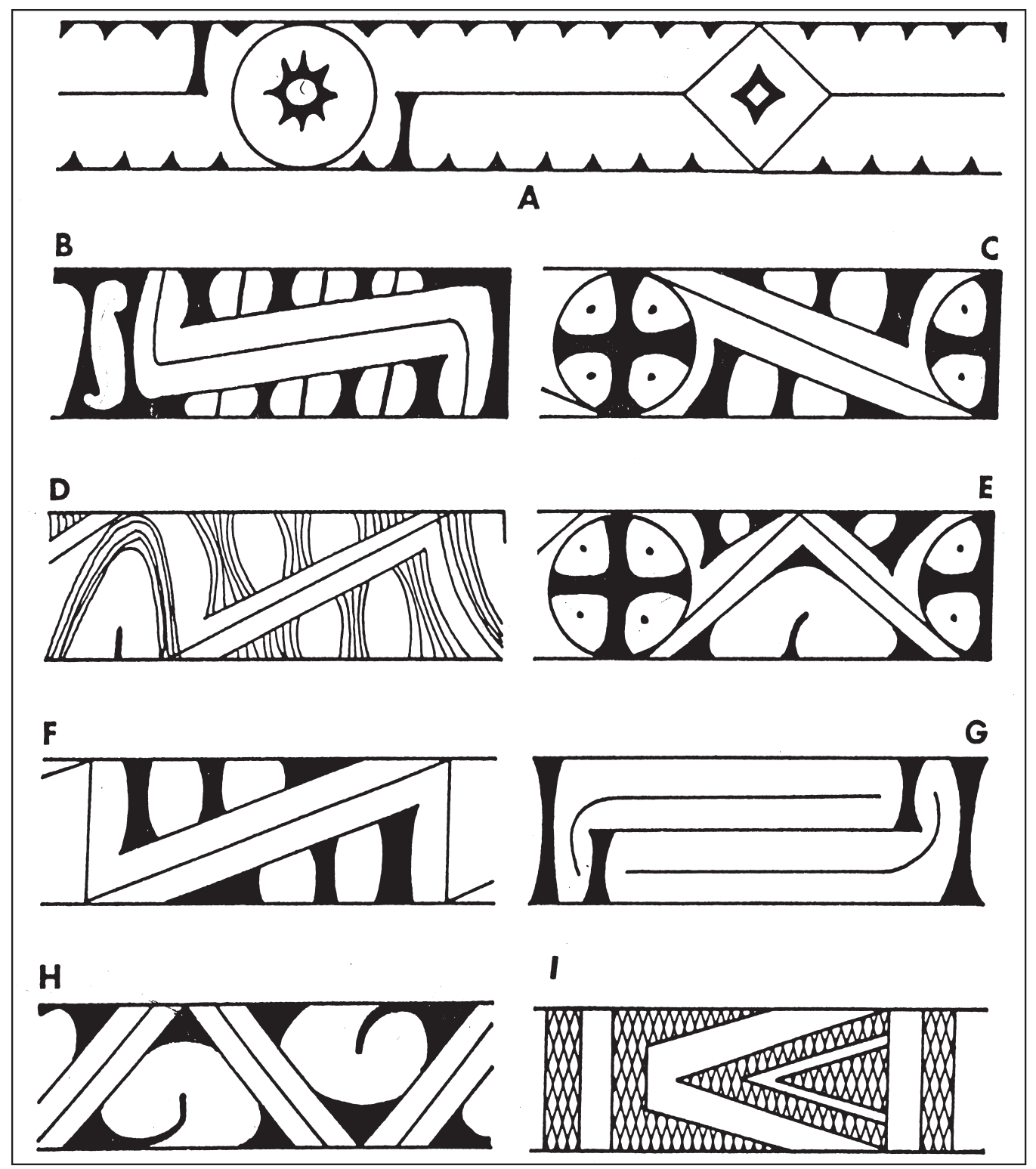

Figure 3. Defined varieties of Ripley Engraved and other engraved motifs on carinated bowls and compound bowls: a, var. McKinney; b, var. Gandy; c, var. Galt; d, var. Caldwell; e, var. Cash; f, var. Carpenter; g, var. Pilgrims; h, var. Williams; i, var. Reed. 


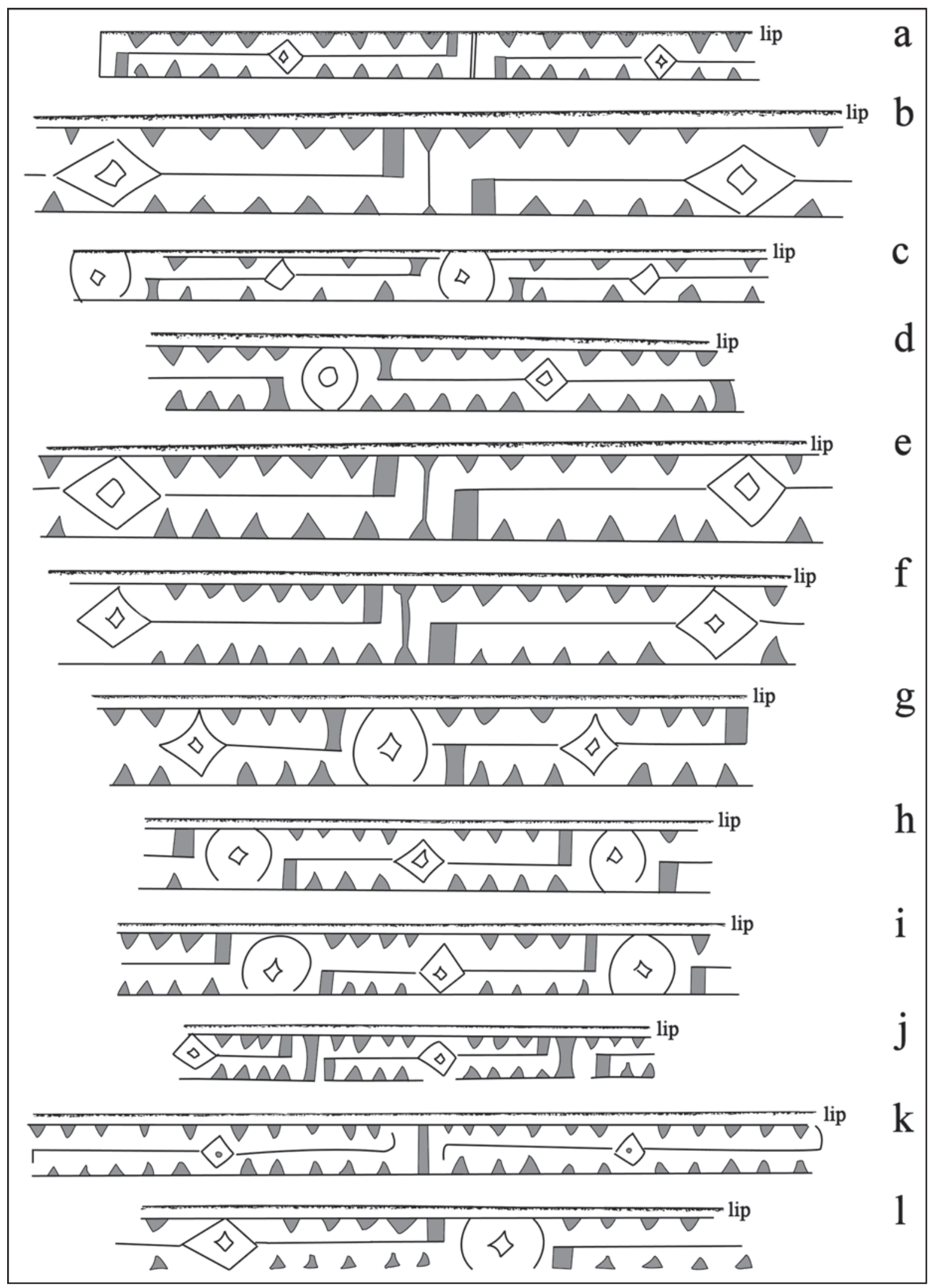

Figure 4. Rim motifs on Ripley Engraved, var. McKinney vessels from the Harold Nix site: a, Burial 2; b-d, Burial 3; e-g, Burial 4; h-i, Burial 5; j, Burial 6; k-m, Burial 7; n-q, Burial 8; r-v, Burial 9. 


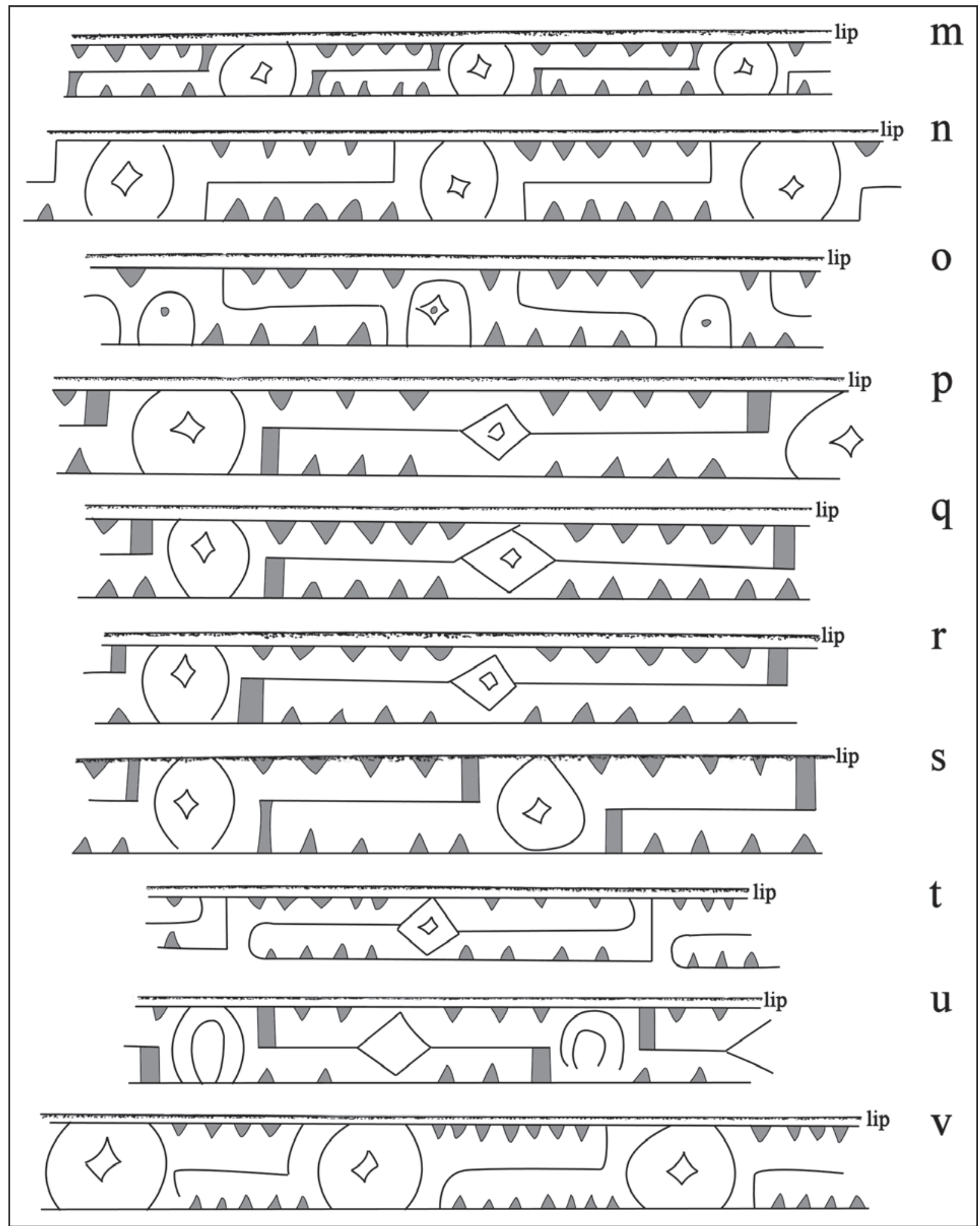




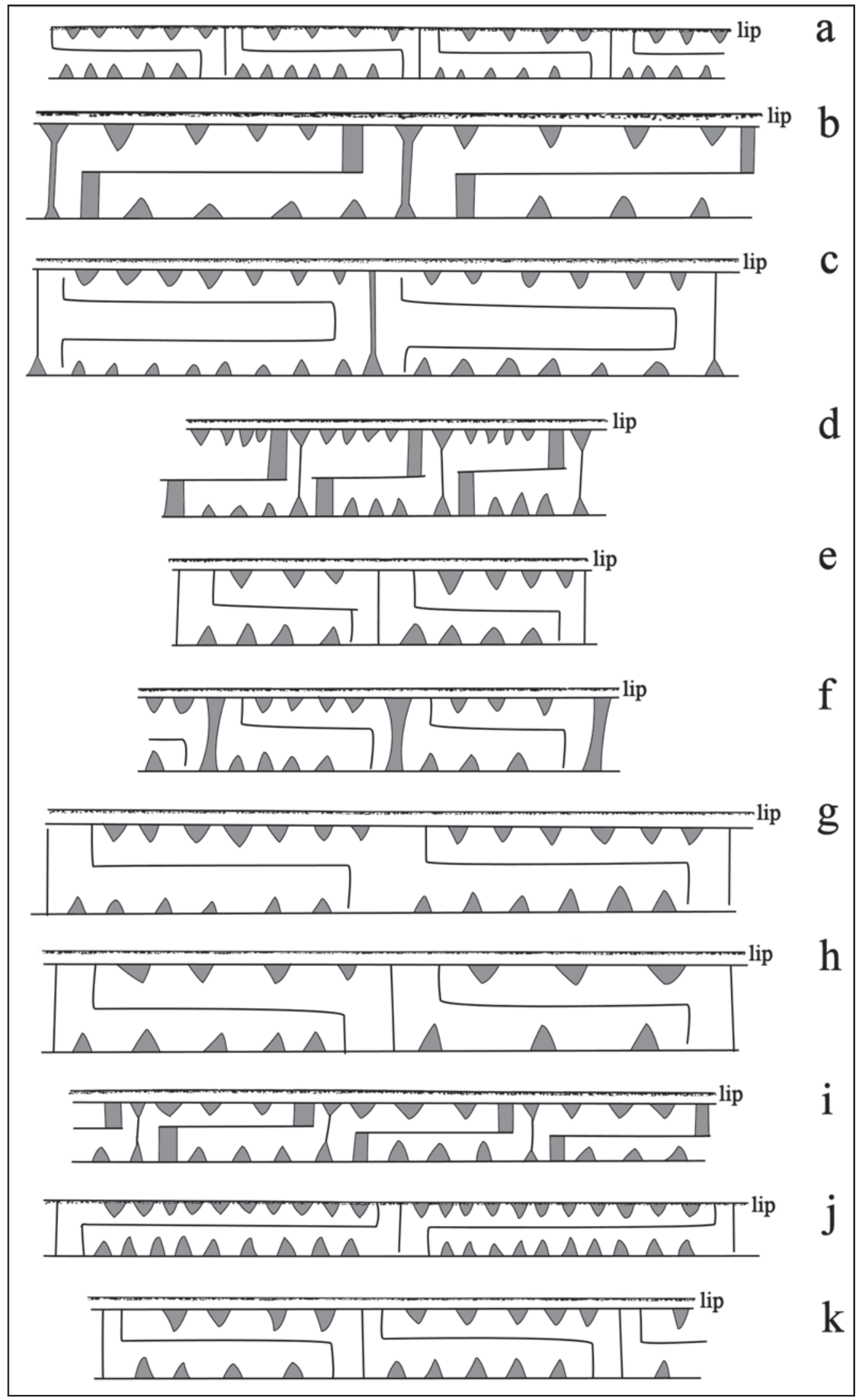

Figure 5. Rim motifs on Ripley Engraved, var. Nix vessels from the Harold Nix site: a, Burial 2; b-c, Burial 3; d, Burial 4; e-f, Burial 5; g-h, Burial 6; i, Burial 7; j-k, Burial 8. 
Four vessels (8.2 percent) are Ripley Engraved vessels that have combinations of var. McKinney (pendant triangles) and var. Gandy (curvilinear scroll and excised bracket dividers) (Figure 6a-d); they are referred to as Ripley Engraved, var. McKinney-Gandy for lack of a better term. There are single examples of var. Cash (Figure 7a), var. Gandy (Figure 7b), var. Pilgrims (Figure 7c), and var. Galt (Figure 7d) in the vessel assemblage.

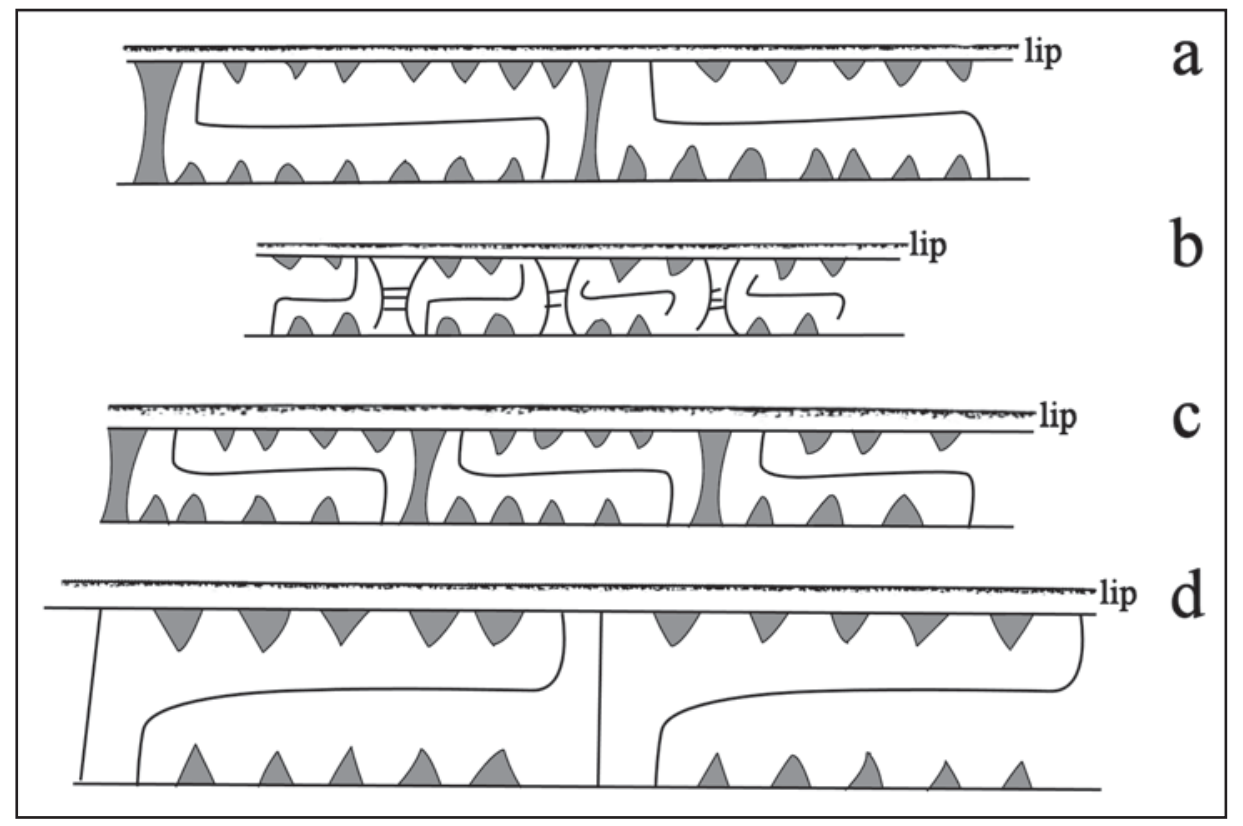

Figure 6. Rim motifs on Ripley Engraved, var. McKinney-Gandy vessels from the Harold Nix site: a, Burial 2; b, Burial 5; c, Burial 6; d, Burial 8.

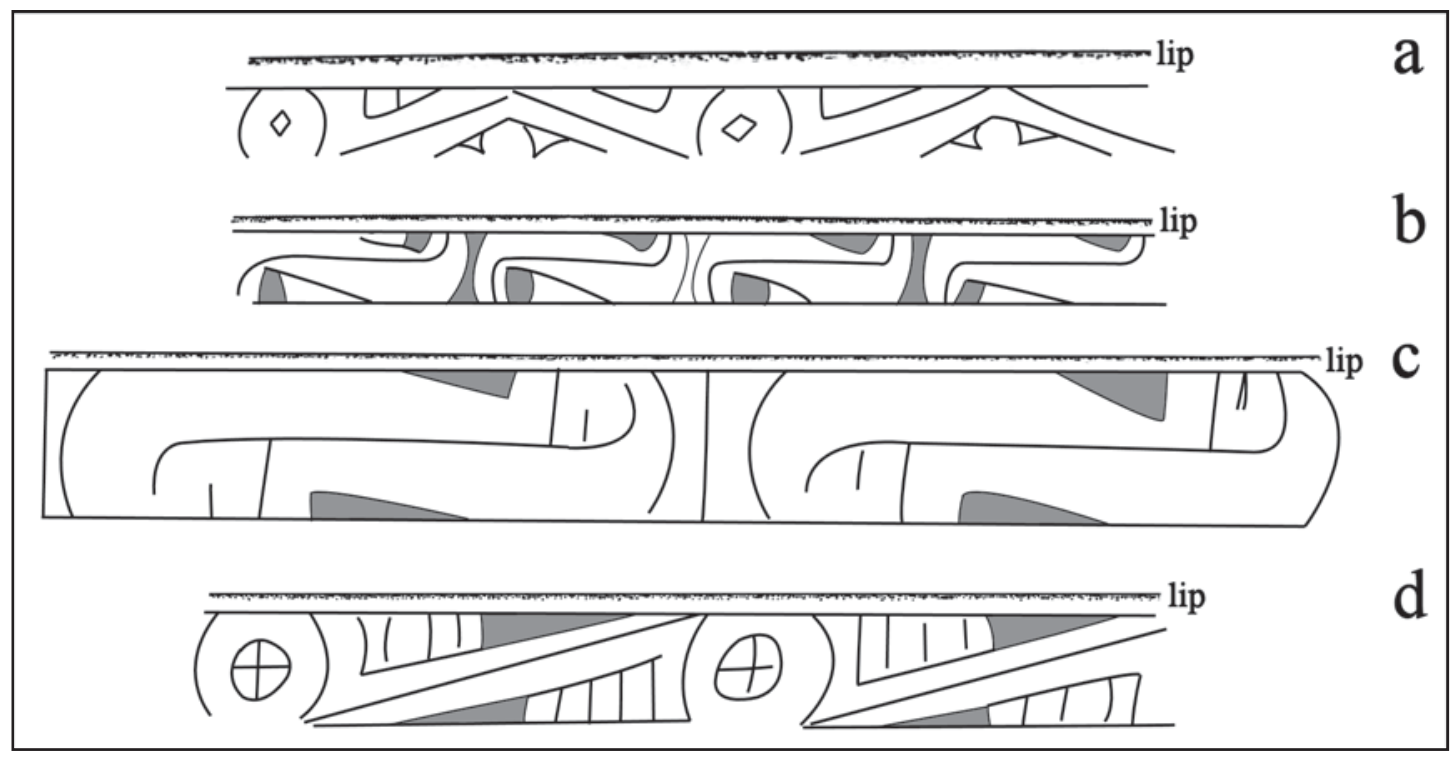

Figure 7. Rim motifs on other Ripley Engraved variety vessels from the Harold Nix site: a, Burial 2; b, Burial 3; c, Burial 8; d, Burial 8. 
Other fine ware types in the ceramic vessel funerary offerings include Taylor Engraved (Figure 8a-b), Simms Engraved (Figure 9a-b), a shell-tempered Bowie Engraved (Figure 10) vessel likely originating among McCurtain phase Caddo peoples on the Red River, and Turner Engraved, a newly defined type on compound bowls (Figure 11). The Bowie Engraved vessel has excised brackets, horizontal scroll lines, and a lower row of excised pendant triangles (cf. Suhm and Jelks 1962:Plate 9).The one Turner Engraved vessel is a var. Turner compound bowl with rim peaks and excised pendant triangles on the lower rim panel (Figure 12). The occurrence of Taylor Engraved, Bowie Engraved, and Simms Engraved vessels is consistent with the use of the Caddo cemetery between ca. A.D. 1550-1680.

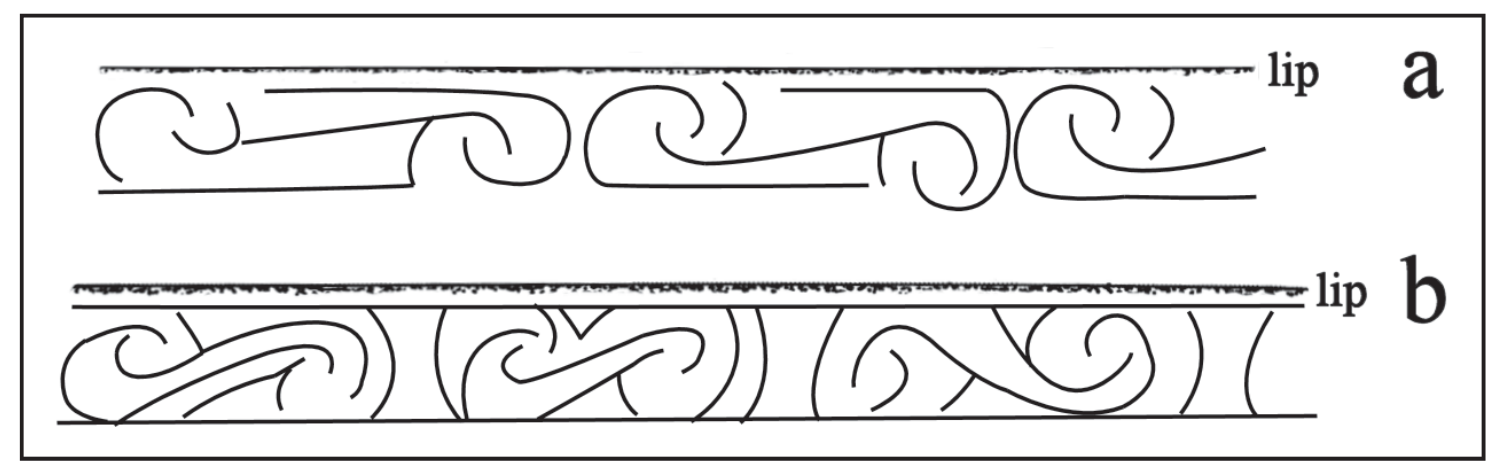

Figure 8. Rim motifs on Taylor Engraved vessels from the Harold Nix site: a, Burial 3; b, Burial 10.

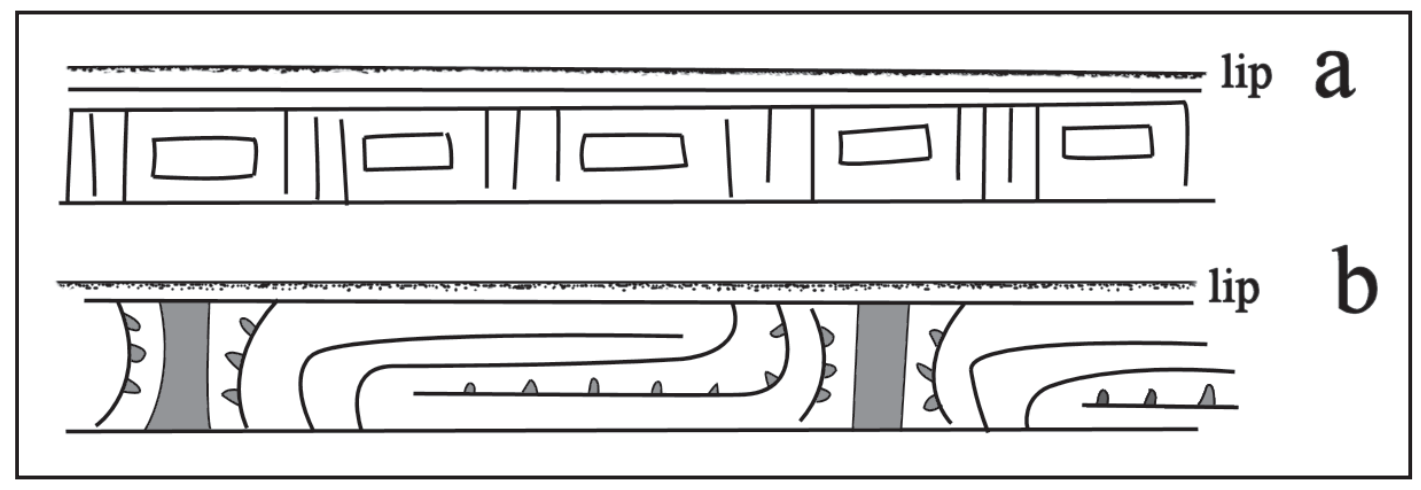

Figure 9. Rim motifs on Simms Engraved vessels from the Harold Nix site: a, Burial 6; b, Burial 8.

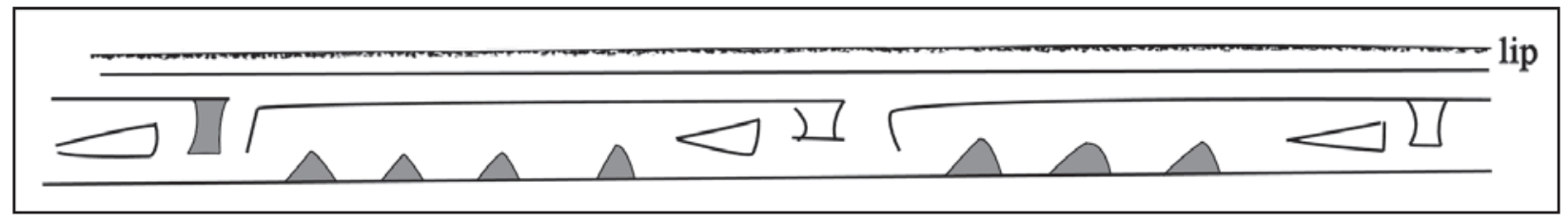

Figure 10. Rim motif on Bowie Engraved vessel from Burial 5 at the Harold Nix site. 


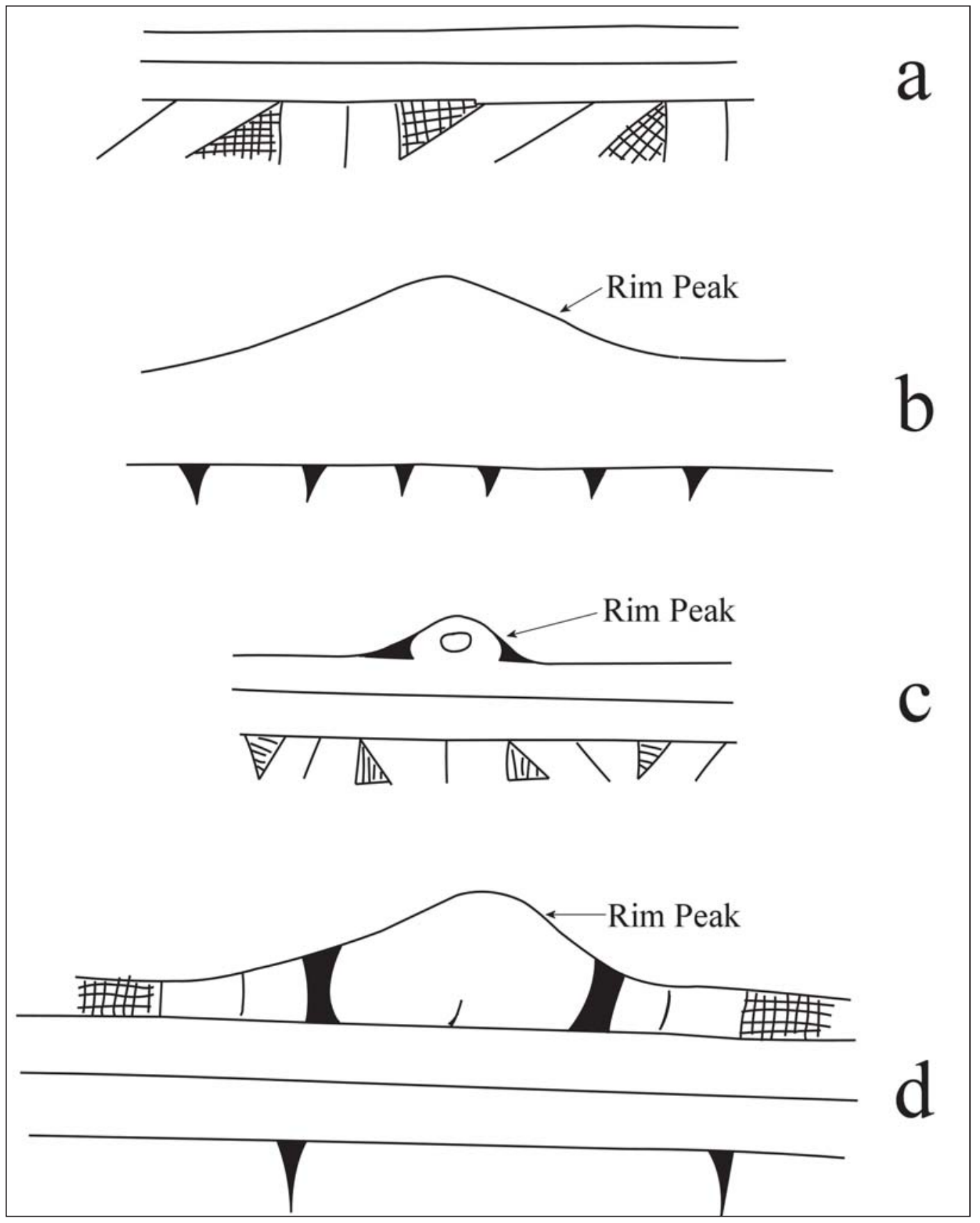

Figure 11. Turner Engraved and defined varieties: a-b, Turner Engraved, var. Turner; c-d, Turner Engraved, var. Horton.

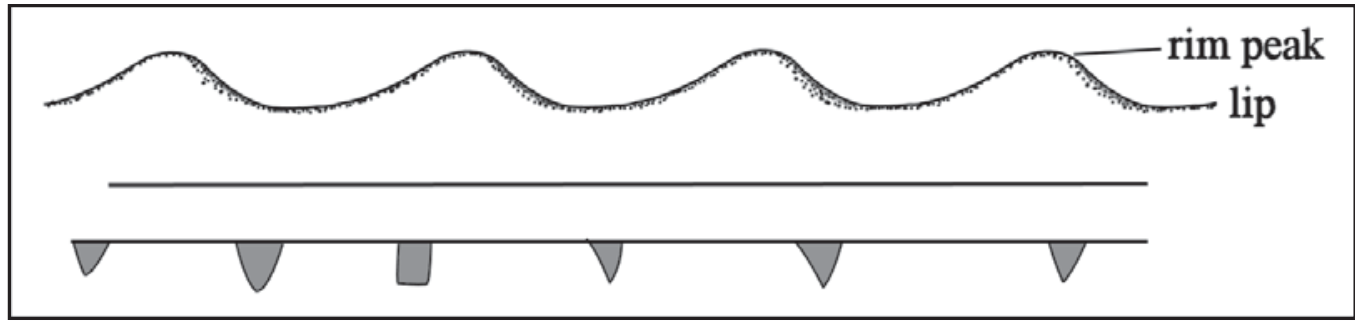

Figure 12. Rim motif on Turner Engraved, var. Turner compound bowl from Burial 8 at the Harold Nix site. 
There are three fine ware engraved vessels that are not identified with a defined East Texas ceramic type. The first is an inverted rim carinated bowl from Burial 8 that has hatched ovals (Figure 13a). This vessel form and decorative motif resembles Womack Engraved carinated bowls from contemporaneous late Titus phase cemeteries along Gum Creek in the Little Cypress Creek basin (Perttula et al.

2012:Figures 19, 40, and 50). The second vessel, from Burial 9, has a slanted scroll motif and is probably from a Ripley Engraved compound bowl, as seem on var. Gandy, var. Galt, and var. Carpenter, but the scrolls are separated by a ticked hooked arm element as documented on certain Wilder Engraved bottles (Figure 13b), rather than vertical brackets with SZ elements (var. Gandy) or circles and crosses (var. Galt). The last engraved vessel with a drawn rim motif, also from Burial 9, has an idiosyncratic decoration comprised of semi-circles, concentric semi-circles, and dividing vertical and rectangular elements (Figure 13c).

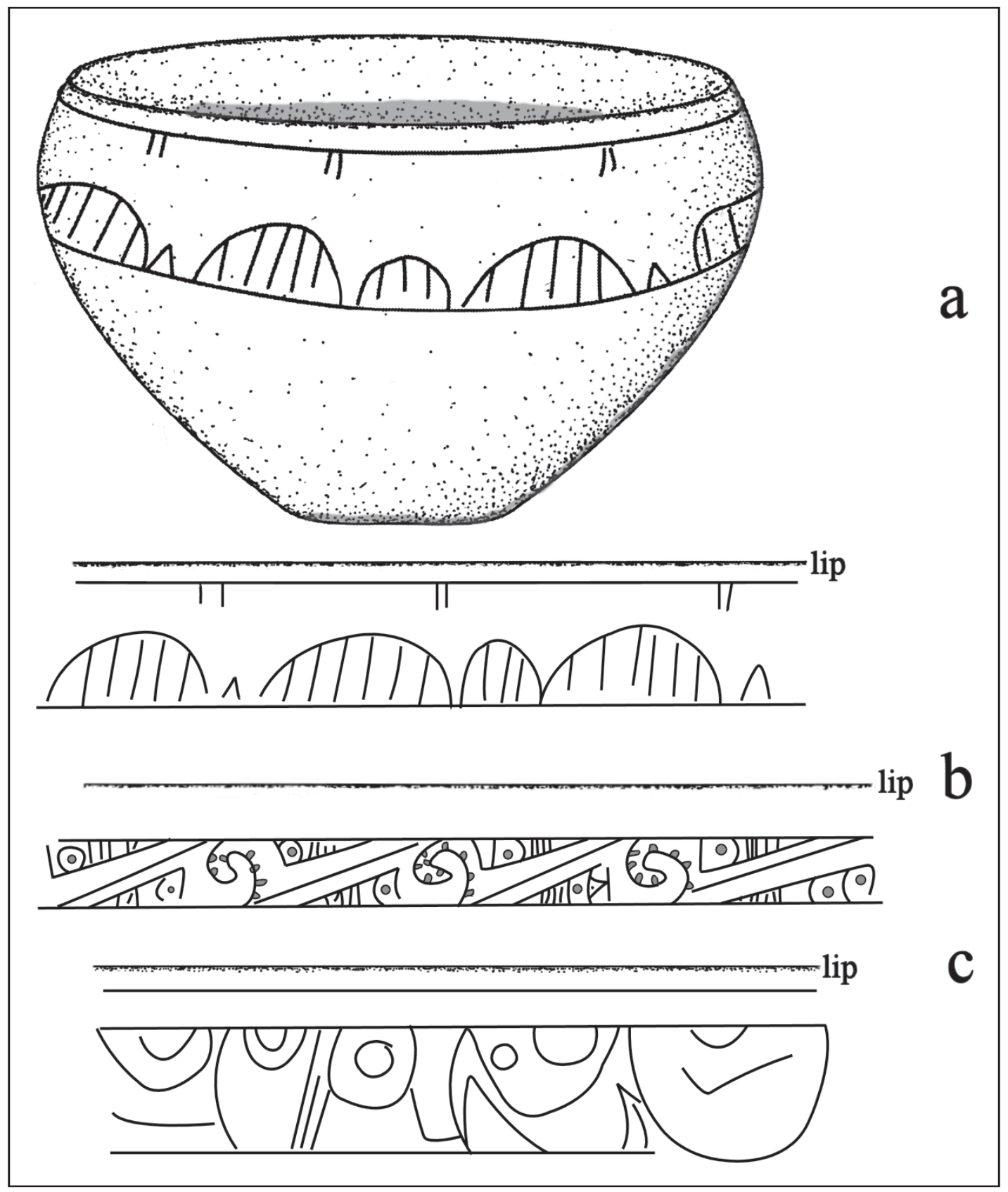

Figure 13. Rim motifs on other engraved vessels from the Harold Nix site: a, Burial 8; b, Burial 9; c, Burial 9. 


\section{Ceramic Pipe and Ceramic Ear spool}

A single ceramic elbow pipe and (ceramic) ear spool were among the funerary offerings in Burial 1. Nicholas' notes provide no further information about these offerings. While ceramic ear spools are the most common form made and used by Titus phase peoples, it is possible that this ear spool was made of stone, as stone ear spools have been found as funerary offerings in burials at the Pine Tree Mound (41HS15, Fields and Gadus 2012:596-601) and Tuck Carpenter (41CP5, Turner 1992:72) sites.

\section{Talco Arrow points}

Talco arrow points are lanceolate-shaped forms with "straight to recurved lateral edges and a slightly concave base. The lateral edges are commonly minutely serrated" (Turner et al. 2011:212). Turner (1978, 1992) and Perttula (1992) have suggested that Talco arrow points were made and used only late in the Titus phase, after ca. A.D. 1550 (or even later), following the arrow point sequence of Perdiz points made and used first during the phase, followed by Bassett, Maud, and then Talco types. As mentioned above, Talco arrow points were recovered as funerary offerings in only three of the burials at the Harold Nix site.

\section{Celts}

Ground stone celts were funerary offerings in two of the burial features at the Harold Nix site (see Table 1). Celts are not common funerary offerings in Titus phase sites, as Fields et al. (2014:424) have demonstrated by a detailed study of 238 Titus phase burials from 14 cemeteries in the same general area of East Texas as the Harold Nix site. Only 16 graves (6.7 percent) had celts as funerary offerings.

\section{Summary and Conclusions}

The Harold Nix site on Boggy Creek in the Big Cypress Creek basin is an ancestral Caddo family cemetery discovered in 1995 on land owned by Harold Nix in Morris County. Nix asked Ralph Nicholas to excavate the burial features at the site to recover the associated funerary offerings, and all told, 20 Caddo burial features were uncovered during the work. Nicholas' notes were turned over to Robert L. Turner in 1998, and he forwarded them to the Texas Archeological Research Laboratory at The University of Texas that same year.

The available notes on the burial features in the cemetery, and their associated funerary offerings, indicate that ceramic vessels $(n=120)$ were placed in each burial feature, but at the low range of offerings documented in other Titus phase cemeteries in the region, along with Talco arrow points $(n=26)$, celts $(n=2)$, a ceramic pipe, and an ear spool (probably of ceramic manufacture). Identified ceramic types included as funerary offerings are vessels of Harleton Appliqued, La Rue Neck Banded, Ripley Engraved, Cass Appliqued, Bailey Engraved, Maydelle Incised, Taylor Engraved, Simms Engraved, Bowie Engraved (shell-tempered), Turner Engraved, Wilder Engraved, and Nash Neck Banded (shelltempered).

Rim motif drawings by Nicholas of engraved fine ware vessels in Burials 2-10 in the cemetery indicate that Ripley Engraved vessels (mainly carinated bowls) comprise 85.7 percent of the fine ware vessels in these burials. Of these vessels, about half are of the Ripley Engraved, var. McKinney type, and another 22 percent are Ripley Engraved, var. Nix vessels. The combination of these varieties, which appear to have been made and used as funerary offerings during the latter part of the Titus phase (see Turner 1978, 1992; Perttula 1992), strongly suggest that the cemetery at the Harold Nix site was used by Caddo peoples between ca. A.D. 1550-1680. This temporal estimate for Caddo cemetery use is bolstered by the association of these vessels in burial features with Talco arrow points, and post-A.D. 1550 Caddo vessels from Taylor Engraved, Simms Engraved, Bowie Engraved, and Cass Appliqued vessels. 


\section{Acknowledgments}

Lance Trask prepared the figures in this article.

\section{References Cited}

Fields, R. C. and E. F. Gadus (editors)

2012 Archeology of the Nadaco Caddo: The View from the Pine Tree Mound Site (41HS15), Harrison County, Texas. 2 Vols. Reports of Investigations No. 164. Prewitt and Associates, Inc., Austin.

Fields, R. C., V. L. Hatfield, D. Burden, E. F. Gadus, M. C. Wilder, and K. W. Kibler

2014 Testing and Data Recovery Excavations at 11 Native American Archeological Sites along the U.S. Highway 271 Mount Pleasant Relief Route, Titus County, Texas. 2 Vols. Reports of Investigations No. 168. Prewitt and Associates, Inc., Austin.

Perttula, T. K.

1992 "The Caddo Nation": Archaeological and Ethnohistoric Perspectives. University of Texas Press, Austin.

2012 The Character of Fifteenth- to Seventeenth-Century Caddo Communities in the Big Cypress Creek Basin of Northeast Texas. In The Archaeology of the Caddo, edited by T. K. Perttula and C. P. Walker, pp. 363-410. University of Nebraska Press, Lincoln.

Perttula, T. K., M. Walters, and B. Nelson

2012 Little Cypress Creek Basin Archaeology: Six Late Caddo Period Cemeteries in Upshur County, Texas. Special Publication No. 22. Friends of Northeast Texas Archaeology, Austin and Pittsburg.

Suhm, D. A. and E. B. Jelks (editors)

1962 Handbook of Texas Archeology: Type Descriptions. Special Publication No. 1, Texas Archeological Society, and Bulletin No. 4, Texas Memorial Museum, Austin. Reprinted in 2009, Gustav's Library, Davenport, Iowa.

Turner, E. S., T. R. Hester, and R. L. McReynolds

2011 Stone Artifacts of Texas Indians. Taylor Trade Publishing, Lanham, Maryland.

Turner, R. L.

1978 The Tuck Carpenter Site and Its Relations to Other Sites within the Titus Focus. Bulletin of the Texas Archeological Society 49:1-110.

1992 Prehistoric Mortuary Remains at the Tuck Carpenter Site, Camp County, Texas. Studies in Archeology No. 10. Texas Archeological Research Laboratory, The University of Texas at Austin. 